\title{
Critical period of weed interference on total polyphenol content in quinoa
}

\author{
Jorge Merino ${ }^{1,3}$, Alberto Pedreros²*, Susana Fischer ${ }^{2}$, and María D. López ${ }^{2}$ \\ 'Instituto Nacional de Investigaciones Agropecuarias (INIAP), Estación Experimental Santa Catalina, Pichincha, Ecuador. \\ ${ }^{2}$ Universidad de Concepción, Facultad de Agronomía, Av. Vicente Méndez 595, Chillán, Chile. \\ *Corresponding author (jpedrerosl@udec.cl). \\ ${ }^{3}$ Universidad de Concepción, Programa de Doctorado en Ciencias de la Agronomía, Av. Vicente Méndez 595, Chillán, Chile.
}

Received: 17 December 2018; Accepted: 7 February 2019; doi:10.4067/S0718-58392019000300405

\begin{abstract}
There is limited information about the critical period of weed interference (CPWI) in quinoa (Chenopodium quinoa Willd.) and the effect produced by the weed-crop interaction in secondary metabolite accumulation. The objective of the present study was to determine the CPWI and its effect on total polyphenol content in quinoa. The experiments were conducted during two consecutive seasons using a randomized complete block design with 16 treatments consisting of 8 weed growth periods and 8 weed-free growth periods in which weed population and biomass were evaluated; productive parameters, yield components, and total polyphenols were determined in the quinoa crop. Grain number per plant affected yield because of weed interference $(\mathrm{P}<0.05)$, which decreased from 4312 to 162 grains plant $^{-1}$ in weed growth periods and increased from 181 to 5110 grains plant ${ }^{-1}$ in weed-free growth periods. Total polyphenol content was affected by stress from weed interference $(\mathrm{P}<0.05)$, which increased from 2.2 gallic acid equivalents $(\mathrm{GAE}) \mathrm{g}^{-1}$ to $3.6 \mathrm{mg} \mathrm{GAE} \mathrm{g}^{-1}$ in weed growth periods and decreased from $3.6 \mathrm{GAE} \mathrm{g}^{-1}$ to $1.9 \mathrm{mg} \mathrm{GAE} \mathrm{g}^{-1}$ in weed-free growth periods, while the population remained constant $(\mathrm{P}>0.05)$. The $\mathrm{CPWI}$ was determined between the phenological stages of two true leaves to flowering; therefore, the quinoa crop must remain weed-free between these two phenological stages to rule out production losses greater than $5 \%$.
\end{abstract}

Key words: Chenopodium quinoa, critical period of weed interference, stress from weed interference, total polyphenols, weed control in quinoa.

\section{INTRODUCTION}

Quinoa (Chenopodium quinoa Willd.) is a pseudocereal belonging to the Amaranthaceae family with high nutritional value originating from the Andes region. It is grown in several countries of South America where the cultivated area has increased in the last 20 years and is destined to food for humans (Abugoch, 2009). The quinoa grain also contains high amounts of protein and exhibits an optimum content of amino acids, minerals, vitamins, polyphenols, and flavonoids (Abugoch, 2009; Repo-Carrasco-Valencia et al., 2010). Important amounts of bioactive components such as polyphenols (Alvarez-Jubete et al., 2010), mainly phenolic acids such as caffeic, ferulic, $p$-coumaric, $p$-hydroxybenzoic, vinyl, gallic, cinnamic acids (Pasko et al., 2008; Repo-Carrasco-Valencia et al., 2010), and flavonoids have also been found in its grains. All these bioactive compounds have been reported to provide benefits for human health (Dini et al., 2010).

Although quinoa is a traditionally low-yield crop in the regions of origin, increased demand for its abovementioned benefits has led to increased production. Among the pending problems to be studied are those related to weeds because production decreases as density and duration of weed interference increase. Another factor that interferes with yield is the relationship between weed emergence and the pressure exerted on the crop (Fahad et al., 2014). Yield losses caused 
by ineffective weed control are usually higher than losses caused by pests and diseases (Oerke, 2006). In this way weeds are a limiting factor in the quinoa crop; they directly affect yield because they compete for factors such as water, nutrients, and light. The intensity and duration of weed interference are factors that determine the extent of yield losses (Swanton et al., 2015).

The critical period of weed interference (CPWI) can be defined as the stage in the growth cycle of any crop during which weeds must be controlled to prevent unrecoverable yield losses. Knowledge of crop CPWI also contributes to minimize yield losses that this crop can exhibit due to weed infestation (Safdar et al., 2016); determining CPWI is an indispensable tool to propose effective weed management strategies in any crop production system (Tursun et al., 2016). Information about CPWI in quinoa and its effect on yield is very limited; therefore, findings in other crops encourage research on the effect of weeds on quinoa and define when weed management is more efficient. However, weed interference not only affects crop yield but also alters the amount of plant secondary metabolites, which accomplish important functions within the plants (Olivoto et al., 2016). Provoked stress in the plants also increases polyphenol concentration in the tissues but reduces biomass production (De Abreu and Mazzafera, 2005).

Manual weed control methods in quinoa are an important factor that directly interferes with yield; the effect of weedcrop interaction on total polyphenol content in the grain such as stress indicators are still unknown. Therefore, the objective of the present study was to determine the CPWI in quinoa and its effect on total polyphenol content.

\section{MATERIALS AND METHODS}

\section{Plant material and experimental design}

The experiments were conducted during two consecutive seasons in the El Nogal Experimental Station (36 $34^{\prime}$ S and $74^{\circ} 06^{\prime} \mathrm{W}$ ) in Nuble Region, Chile. A randomized complete block experimental design was used with four replicates. The experimental unit was $3 \times 2 \mathrm{~m}$ and consisted of four rows of quinoa 'Regalona' plants with $0.5 \mathrm{~m}$ spacing. A modified version of the methodology proposed by Karkanis et al. (2012) was used; each block contained 16 treatments at 0, 15, 30, 45, 60, 75, 90, and $105 \mathrm{~d}$ after emergence consisting of 8 weed growth periods and 8 weed-free growth periods (Table 1). This allowed determining the beginning and the end of the period needed to eliminate weeds.

\section{Agronomic management}

The soil was prepared using one pass with a moldboard plow, two passes with a disc harrow plow, and two passes with a vibro-cultivator in each season. Continuous manual sowing was performed in mid-October at a $12 \mathrm{~kg} \mathrm{ha}^{-1}$ seeding rate and $0.5 \mathrm{~m}$ row spacing. The soil at the experimental site exhibited 6.8 neutral $\mathrm{pH}, 8.6 \mathrm{mg} \mathrm{kg}^{-1}$ available $\mathrm{N}, 6 \mathrm{mg} \mathrm{P}$ $\mathrm{kg}^{-1}$, and $626.0 \mathrm{mg} \mathrm{K} \mathrm{kg}^{-1}$ according to soil analysis; therefore, fertilization was uniformly applied as $100 \mathrm{~kg}_{2} \mathrm{O}_{5}$ ha $^{-1}$ and $50 \mathrm{~kg} \mathrm{~K}_{2} \mathrm{O} \mathrm{ha}^{-1}$ before sowing together with $160 \mathrm{~kg} \mathrm{~N} \mathrm{ha}^{-1}$ of which $50 \%$ was applied at the 4 true leaf stage and $50 \%$ at the beginning of branching. Furrow irrigation was used to facilitate homogeneous water flow, and mechanical/manual weed removal was carried out with a hand hoe in accordance with the treatments at biweekly intervals.

\section{Determination of critical period of weed interference (CPWI)}

Quinoa population and growth were evaluated at $0,15,30,45,60,75,90$, and $105 \mathrm{~d}$ after emergence. Measurements were taken in two linear meters in the two central rows of each plot; plant height $(\mathrm{PH})$ was measured from the root collar

Table 1. Description of treatments in weed and weed-free growth periods in the 2015-2016 and 2016-2017 seasons.

\begin{tabular}{crcr}
\hline Treatment & $\begin{array}{c}\text { Weed growth } \\
\text { periods }\end{array}$ & Treatment & $\begin{array}{c}\text { Weed-free } \\
\text { growth periods }\end{array}$ \\
\hline 1 & 0 d with weeds & 9 & 0 d weed-free \\
2 & 15 d with weeds & 10 & 15 d weed-free \\
3 & 30 d with weeds & 11 & 30 d weed-free \\
4 & 45 d with weeds & 12 & 45 d weed-free \\
5 & 60 d with weeds & 13 & 60 d weed-free \\
6 & 75 d with weeds & 14 & 75 d weed-free \\
7 & 90 d with weeds & 15 & 90 d weed-free \\
8 & 105 d with weeds & 16 & 105 d weed-free \\
\hline
\end{tabular}


to the apex of the panicle in the first seven plants from the selected section. Each treatment was associated with the crop phenological stages proposed by Mujica and Canahua (1989). Likewise, yield per unit area $\left(\mathrm{kg} \mathrm{ha}^{-1}\right)$ was determined from the two linear meters of the two central rows of each plot. To estimate grain number per plant and biomass per plant $(\mathrm{g})$, the mean of the seven first plants in the two linear meters of the two central rows of each plot was considered. The 1000 grains weight $(\mathrm{g})$ variable was determined by recording the weight of 1000 quinoa seeds without considering the perigonium, and this was accomplished by separating the grains from the chaff.

\section{Determination of total polyphenols in quinoa seeds}

Quinoa samples $(20 \mathrm{~g})$ from each of the 16 treatments that included both weed and weed-free growth periods were ground in a grinder (1093, Cyclotec, Barcelona, Spain). Extracts were prepared according to a modified version of the method described by Fischer et al. (2013). The supernatant was filtered, placed in amber glass jars, and stored at $4{ }^{\circ} \mathrm{C}$ until analyzed. A modified version of the method described by Miranda et al. (2010) was used to determine total polyphenols. Results were expressed as mg gallic acid equivalents (GAE) $\mathrm{g}^{-1}$ and all measurements were performed in triplicate.

\section{Weed evaluations}

Quinoa weed population and DM were evaluated by sampling according to a modified version of the method proposed by Stagnari and Pisante (2011); a quadrant with $0.5 \times 0.5 \mathrm{~m}$ was traced $1 \mathrm{~m}$ inside between two central rows of each experimental unit and weed population and DM were extracted with weed growth periods for weeding at $0,15,30,45$, $60,75,90$, and $105 \mathrm{~d}$ after emergence. Weeds were cut at soil level, placed in paper bags, and oven-dried (FP 115, Binder, Tuttlingen, Germany) at $65^{\circ} \mathrm{C}$ for $72 \mathrm{~h}$.

\section{Statistical analysis}

Data was subjected to ANOVA at $\mathrm{P}<0.05$ after verifying the assumptions of normal distribution and homogeneity of variances. These assumptions were not fulfilled in yield data (data not shown and necessary to calculate the CPWI) and transformations were performed with the $\ln (\mathrm{x}+1)$ function. Means were compared by the LSD test at the $95 \%$ significance level.

The CPWI was determined by non-linear regressions adjusted to the Gompertz and simple logistic models. The Gompertz equation was used to model the effect of weed growth periods on relative grain yield, while the logistic equation was used to model the effect of weed-free growth periods on relative grain yield (Singh et al., 2014).

The Gompertz equation $Y=a * \exp \left(-b * \exp \left(-X_{0} * X\right)\right)$ expresses $Y$ as yield, $a$ the asymptote, $b$ the exponential rate, $X_{0}$ the inflection point, and $X$ days after emergence. On the other hand, the logistic equation $Y=a /\left(1+b * \exp \left(-X_{0} * X\right)\right)$ expresses $Y$ as yield, $a$ the lowest asymptote, $b$ yield rate reduction measurement, $X_{0}$ duration of weed interference when maximum yield could be reduced by half over ' $a$ ', and $X$ days after emergence.

The statistical analysis and the curves to estimate the critical period of weed interference were performed with the INFOSTAT statistical program (Di Rienzo et al., 2017). To compare the results of the variables between the first and second season, a combined experiment analysis was performed in which the interaction between year and treatment for all the variables was nonsignificant $(\mathrm{P}>0.05)$; therefore, data were grouped and analyzed together.

\section{RESULTS AND DISCUSSION}

\section{Weed population and biomass}

Weed density was adjusted to a quadratic polynomial model related to days after emergence (DAE) with a significant $(\mathrm{P}<0.05)$ coefficient of determination and a highly significant $\left(\mathrm{R}^{2}=0.81\right)$ relationship. The lowest weed density $(0$ plants $\mathrm{m}^{-2}$ ) was observed in the treatments that were weed-free during the whole experiment $(105 \mathrm{~d}$ weed-free and $0 \mathrm{~d}$ with weeds). After 60 DAE, weed density reached its maximum value and decreased until 105 DAE (Figure 1), while weed DM at this point continued to increase (Figure 2). The decrease in density could be caused by intra- and interspecific competition in which the environmental load capacity was unable to sustain the whole initial population; the remaining plants continued to accumulate biomass, which allowed them to continue their vegetative cycle until harvest. In a similar study with peas, Singh et al. (2016) reported increased weed density until 60 DAE and then observed a downward trend 
Figure 1. Weed density response to increase in days of duration of weed interference after emergence in the quinoa 'Regalona' crop adjusted to a quadratic polynomial model $Y=a_{0}+\left(a_{1} X\right)+\left(a_{2} X^{2}\right)$.

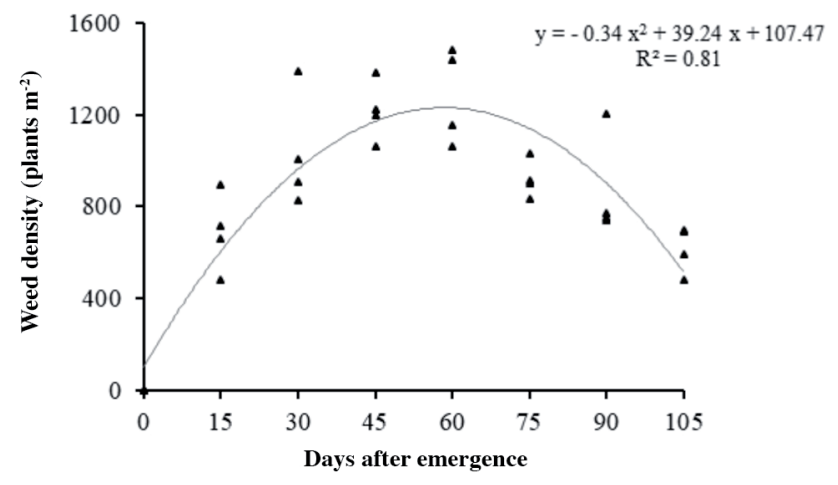

Figure 2. Dry matter biomass response to increase in days of duration of weed interference after emergence. The Gompertz equation adjusted to DM biomass was used.

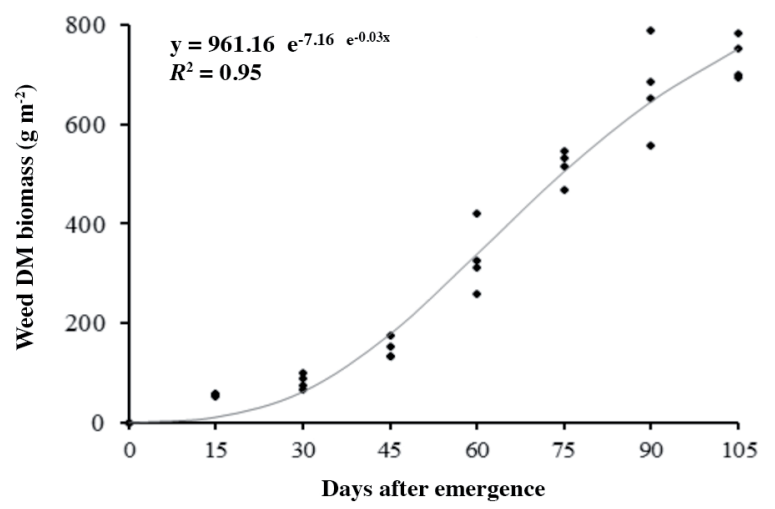

and concluded that most weeds emerge up to 60 DAE. Weed density was also affected by environmental conditions in both seasons (Table 2); weeds faced high precipitation in the early stages, which could cause their higher germination and emergence and result in higher weed density (Tursun et al., 2012). There was also an increase in temperature during the two seasons (Table 2), and this increase can accelerate weed seed germination and increase competition between different species (Giménez et al., 2013).

The weed DM biomass growth curve was adjusted to the Gompertz model, which showed a highly significant $\left(\mathrm{R}^{2}=0.95\right)$ relationship in which the coefficients to determine model parameters $\mathrm{a}, \mathrm{b}$, and $\mathrm{X}_{0}$ were adjusted to the model $(\mathrm{P}<0.05)$ (Figure 2). Maximum weed biomass was recorded in the treatments that had weeds during the whole experiment, that is, $105 \mathrm{~d}$ with weeds and $0 \mathrm{~d}$ weed-free; therefore, weed DM biomass was directly influenced by the increase in the duration of periods of weed interference and increased until harvest. This could be caused by the shade of the highest weeds and of the crop on the germination of new weed populations. These results concur with data reported by Tursun et al. (2016), who detected increased weed biomass until harvest in three types of corn. On the other hand, Stagnari and Pisante (2011)

Table 2. Meteorological data for mean temperature and precipitation at the experimental site for two seasons.

\begin{tabular}{|c|c|c|c|c|}
\hline \multirow[b]{2}{*}{ Month } & \multicolumn{2}{|c|}{ Mean temperature } & \multicolumn{2}{|c|}{ Precipitation } \\
\hline & $2015-2016$ & $2016-2017$ & $2015-2016$ & 2016-2017 \\
\hline & \multicolumn{2}{|c|}{${ }^{\circ} \mathrm{C}$} & \multicolumn{2}{|c|}{$\longrightarrow \mathrm{mm} \mathrm{mo}^{-1}$} \\
\hline October & 12.06 & 13.27 & 98.60 & 65.00 \\
\hline November & 15.13 & 16.65 & 7.40 & 11.60 \\
\hline December & 18.24 & 17.86 & 0.00 & 31.50 \\
\hline January & 20.50 & 21.50 & 7.30 & 3.50 \\
\hline February & 19.95 & 20.40 & 0.00 & 13.00 \\
\hline
\end{tabular}


determined that weed biomass increased as the duration of weed infestation increased in a bean crop. Ahymadvand et al. (2009) also found increased weed DM biomass until harvest in a potato crop and reported that weed biomass was higher in low sowing densities; they concluded that open spaces with low sowing densities could increase weed biomass and that early canopy closure at high sowing densities impede weed growth.

The relationship between quinoa grain yield and weed biomass was adjusted to an exponential model with a significant $(P<0.05)$ coefficient of determination and highly significant $\left(R^{2}=0.80\right)$ relationship. Figure 3 illustrates that grain yield decreased as weed DM biomass increased; therefore, maximum grain yield was obtained in the treatments that remained weed-free during the whole experiment $(0 \mathrm{~d}$ with weeds and $105 \mathrm{~d}$ weed-free). On the other hand, the lowest grain yields were obtained in the treatments with high weed biomass, that is, the treatments that had weeds during the whole experiment ( $105 \mathrm{~d}$ with weeds and $0 \mathrm{~d}$ weed-free). This implies that higher weed biomass maintained until later stages can damage crop production because of the weed-crop competition for water, light, and nutrients, which directly affected quinoa yield. Similar studies in other crops have demonstrated yield reduction due to weed interference. Qasem (2009) determined that mean cauliflower yield decreased and was directly affected by weed interference during the crop season. Meanwhile, Singh et al. (2014) reported a negative linear relationship between grain yield and weed DM biomass in rice where treatments with higher weed DM biomass caused a loss of up to $100 \%$ of crop yield compared with treatments with lower weed biomass; therefore, weeds would constitute an important restrictive biotic factor that influences yield.

\section{Critical period of weed interference (CPWI)}

The quinoa population remained constant $(\mathrm{P}>0.05)$ in all periods, whereas $\mathrm{PH}$ varied $(\mathrm{P}<0.05)$ in the weed $($ Table 3$)$ and weed-free (Table 4) growth periods. Thus, quinoa PH increased as the duration of weed interference decreased, that is, as the number of days increased in which treatments remained weed-free. In the weed growth periods (Table 3), PH did not show much difference between treatments $(\mathrm{P}>0.05)$ up to $30 \mathrm{DAE}$; then at $45 \mathrm{DAE}$, treatments with only 0 and 15 $\mathrm{d}$ with weeds exhibited higher values $(68.3$ and $64.1 \mathrm{~cm}$, respectively) than the mean of the other treatments. At $60 \mathrm{DAE}$,

Figure 3. Grain yield response to increase in weed DM biomass in the quinoa 'Regalona' crop adjusted to an exponential model $\mathbf{Y}=\mathbf{a} * \exp (\mathbf{b} \mathbf{X})$.

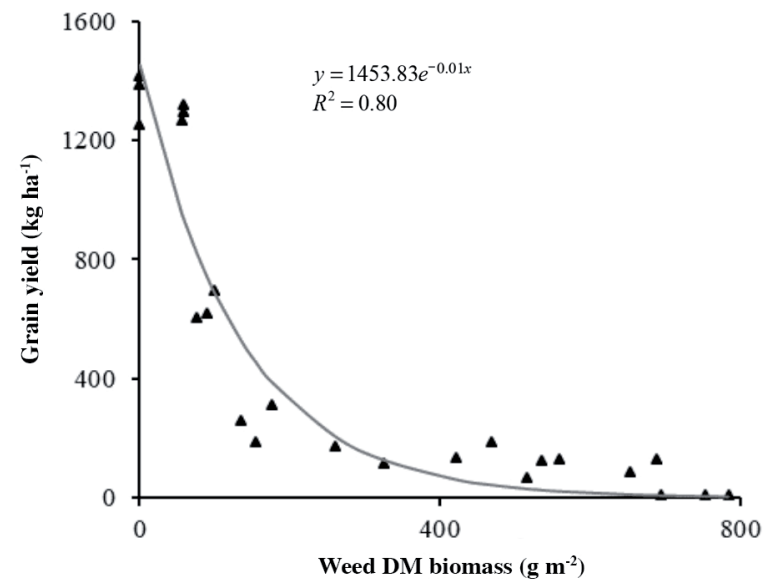

Table 3. Plant height response to weed growth periods expressed as days after emergence (DAE) of the quinoa 'Regalona' crop.

\begin{tabular}{|c|c|c|c|c|c|c|c|c|}
\hline Treatments & $0 \mathrm{DAE}$ & $15 \mathrm{DAE}$ & $30 \mathrm{DAE}$ & $45 \mathrm{DAE}$ & $60 \mathrm{DAE}$ & $75 \mathrm{DAE}$ & $90 \mathrm{DAE}$ & $105 \mathrm{DAE}$ \\
\hline $0 \mathrm{~d}$ with weeds & $1.8 \mathrm{a}$ & $6.1 \mathrm{a}$ & $15.2 \mathrm{a}$ & $68.3 \mathrm{a}$ & $80.5 a$ & $81.1 \mathrm{a}$ & $83.3 \mathrm{a}$ & $83.9 \mathrm{a}$ \\
\hline $15 \mathrm{~d}$ with weeds & $1.8 \mathrm{a}$ & $5.3 b$ & $15.0 \mathrm{a}$ & $64.1 \mathrm{a}$ & $75.1 \mathrm{~b}$ & $76.3 \mathrm{a}$ & $77.1 \mathrm{a}$ & $79.4 b$ \\
\hline $30 \mathrm{~d}$ with weeds & $1.9 \mathrm{a}$ & $5.2 \mathrm{~b}$ & $12.9 \mathrm{~b}$ & $42.5 b$ & $46.1 \mathrm{c}$ & $47.7 b$ & $49.3 b$ & $49.5 \mathrm{c}$ \\
\hline $45 \mathrm{~d}$ with weeds & $1.9 \mathrm{a}$ & $5.2 \mathrm{~b}$ & $12.7 \mathrm{~b}$ & $40.5 b c$ & $43.3 \mathrm{~cd}$ & $45.0 \mathrm{bc}$ & $45.2 \mathrm{bc}$ & $45.7 \mathrm{~cd}$ \\
\hline $60 \mathrm{~d}$ with weeds & $1.8 \mathrm{a}$ & $5.3 b$ & $12.6 b$ & $38.8 \mathrm{bc}$ & $42.7 \mathrm{cde}$ & $44.1 b c$ & $44.2 \mathrm{bcd}$ & 45.0de \\
\hline $75 \mathrm{~d}$ with weeds & $1.9 \mathrm{a}$ & $5.3 b$ & $12.6 b$ & $38.0 \mathrm{c}$ & $39.3 \mathrm{de}$ & $41.0 \mathrm{c}$ & $43.2 \mathrm{~cd}$ & $44.7 \mathrm{de}$ \\
\hline $90 \mathrm{~d}$ with weeds & $1.8 \mathrm{a}$ & $5.3 b$ & $12.6 \mathrm{~b}$ & $36.8 \mathrm{c}$ & $38.8 \mathrm{e}$ & $40.3 \mathrm{c}$ & $40.7 \mathrm{~d}$ & $41.4 \mathrm{e}$ \\
\hline $105 \mathrm{~d}$ with weeds & $1.8 \mathrm{a}$ & $5.3 b$ & $12.5 b$ & $36.5 \mathrm{c}$ & $38.5 \mathrm{e}$ & $40.2 \mathrm{c}$ & $40.5 d$ & $41.0 \mathrm{e}$ \\
\hline
\end{tabular}

The lower-case letters indicate significant differences between treatments (LSD test $\mathrm{P} \leq 0.05$ ). 
Table 4. Plant height response to weed-free growth periods expressed as days after emergence (DAE) of the quinoa 'Regalona' crop.

\begin{tabular}{|c|c|c|c|c|c|c|c|c|}
\hline Treatments & $0 \mathrm{DAE}$ & $15 \mathrm{DAE}$ & $30 \mathrm{DAE}$ & $45 \mathrm{DAE}$ & $60 \mathrm{DAE}$ & $75 \mathrm{DAE}$ & $90 \mathrm{DAE}$ & $105 \mathrm{DAE}$ \\
\hline $0 \mathrm{~d}$ weed-free & $1.8 \mathrm{a}$ & $5.0 \mathrm{~b}$ & $12.8 \mathrm{~b}$ & $49.2 \mathrm{c}$ & $54.0 \mathrm{f}$ & $54.6 \mathrm{f}$ & $54.9 \mathrm{f}$ & $55.0 \mathrm{f}$ \\
\hline $15 \mathrm{~d}$ weed-free & $1.8 \mathrm{a}$ & $5.9 \mathrm{a}$ & $13.0 \mathrm{~b}$ & $64.9 b$ & $69.3 \mathrm{e}$ & $70.6 \mathrm{e}$ & $70.6 \mathrm{e}$ & $70.9 \mathrm{e}$ \\
\hline $30 \mathrm{~d}$ weed-free & $1.9 \mathrm{a}$ & $5.9 \mathrm{a}$ & $14.6 \mathrm{a}$ & $66.9 \mathrm{ab}$ & $76.7 \mathrm{~d}$ & $78.2 \mathrm{~d}$ & $79.8 d$ & $80.0 \mathrm{~d}$ \\
\hline $45 \mathrm{~d}$ weed-free & $1.8 \mathrm{a}$ & $5.8 \mathrm{a}$ & $14.7 \mathrm{a}$ & $68.4 \mathrm{ab}$ & $78.9 \mathrm{~cd}$ & $80.2 \mathrm{~d}$ & $80.5 \mathrm{~d}$ & $80.7 \mathrm{~d}$ \\
\hline $60 \mathrm{~d}$ weed-free & $1.8 \mathrm{a}$ & $5.9 \mathrm{a}$ & $14.9 \mathrm{a}$ & $69.3 \mathrm{ab}$ & $83.4 \mathrm{bc}$ & $84.0 \mathrm{c}$ & $84.2 \mathrm{c}$ & $84.4 \mathrm{c}$ \\
\hline $75 \mathrm{~d}$ weed-free & $1.8 \mathrm{a}$ & $5.8 \mathrm{a}$ & $15.0 \mathrm{a}$ & $70.3 \mathrm{ab}$ & $86.4 \mathrm{~b}$ & $87.7 b$ & $88.1 \mathrm{~b}$ & $88.2 b$ \\
\hline $90 \mathrm{~d}$ weed-free & $1.8 \mathrm{a}$ & $5.9 \mathrm{a}$ & $15.1 \mathrm{a}$ & $71.0 \mathrm{a}$ & $91.3 \mathrm{a}$ & $91.9 \mathrm{a}$ & $92.1 \mathrm{a}$ & $92.2 \mathrm{a}$ \\
\hline $105 \mathrm{~d}$ weed-free & $1.9 \mathrm{a}$ & $5.8 \mathrm{a}$ & $15.2 \mathrm{a}$ & $72.3 \mathrm{a}$ & $92.1 \mathrm{a}$ & $92.8 \mathrm{a}$ & $92.8 \mathrm{a}$ & $93.0 \mathrm{a}$ \\
\hline
\end{tabular}

The lower-case letters indicate significant differences between treatments (LSD test $\mathrm{P} \leq 0.05$ ).

the same treatments with weeds at 0 and $15 \mathrm{~d}$ maintained the trend and showed higher PH ( 80.5 and $75.1 \mathrm{~cm}$, respectively) than the other treatments. In the same period, the weed biomass growth curve, adjusted to the Gompertz equation (Figure 2), continued its upward trend, while weed density adjusted to a quadratic model (Figure 1) reached its maximum value. Finally, the same trend was observed at $105 \mathrm{DAE}$ when the two treatments ( 0 and $15 \mathrm{~d}$ with weeds) were significantly different with values of 83.9 and $79.4 \mathrm{~cm}$, respectively, and these $\mathrm{PH}$ values were higher than for the other treatments. The treatments with lower PH at $105 \mathrm{DAE}$ were those for 105 and $90 \mathrm{~d}$ with weeds; there were no differences between the two and $\mathrm{PH}$ was 41.4 and $41.0 \mathrm{~cm}$, respectively.

In the weed-free growth periods (Table 4), trends were similar to the weed growth periods, and PH up to 30 DAE did not exhibit much difference between treatments. At 45 DAE, the 105 and $90 \mathrm{~d}$ weed-free treatments had higher values than the mean of the other treatments, $72.3 \mathrm{~cm}$ and $71.0 \mathrm{~cm}$, respectively, and there were no differences between the two. At 60 DAE, the same 105 and $90 \mathrm{~d}$ weed-free treatments maintained the trend and exhibited the highest PH with 92.1 and $91.3 \mathrm{~cm}$, respectively; there were no differences between the two but were higher than the other treatments. A similar trend was maintained at $105 \mathrm{DAE}$ in which the two treatments (105 and $90 \mathrm{~d}$ weed-free) did not differ one from the other with values of 93.0 and $92.2 \mathrm{~cm}$, respectively, and they were significantly higher than the other treatments. The treatment that had significantly lower PH was the $0 \mathrm{~d}$ weed-free with a value of $55.0 \mathrm{~cm}$ at 105 DAE.

Plant biomass and the grain number per plant variable were significantly $(\mathrm{P}<0.05)$ influenced by the treatments with weed and weed-free growth periods. For plant biomass, the treatment with $0 \mathrm{~d}$ with weeds (Figure 4A) was higher than the rest of the treatments and had a value of $16.99 \mathrm{~g}$ in the weed growth periods, while in the weed-free growth periods (Figure 4B), treatments with 105, 90, and $75 \mathrm{~d}$ weed-free were significantly equal and had values of 18.5, 18.0, and $18.0 \mathrm{~g}$, respectively. The highest value for the grain number per plant variable occurred in the treatment at $0 \mathrm{~d}$ with weeds (Figure $5 \mathrm{~A})$; the value of 4312 grains plant ${ }^{-1}$ was significantly different from the other treatments in the weed growth periods. Meanwhile, in the weed-free growth periods (Figure 5B), the highest values were found in treatments with 105 and $90 \mathrm{~d}$ weed-free; values were significantly equal at 5110 and 4671 grains plant $^{-1}$, respectively. On the other hand, the 1000 grains weight variable was constant $(\mathrm{P}>0.05$ ) in the weed growth periods (Figure 6A) and in the weed-free growth periods (Figure $6 \mathrm{~B}$ ); values varied between 3.1 and $2.9 \mathrm{~g}$ in weed growth periods and between 3.0 and $2.9 \mathrm{~g}$ in weed-free growth periods.

Figure 4. Plant biomass response to weed interference in the quinoa 'Regalona' crop in the growth periods (A) with weeds and $(B)$ weed-free.
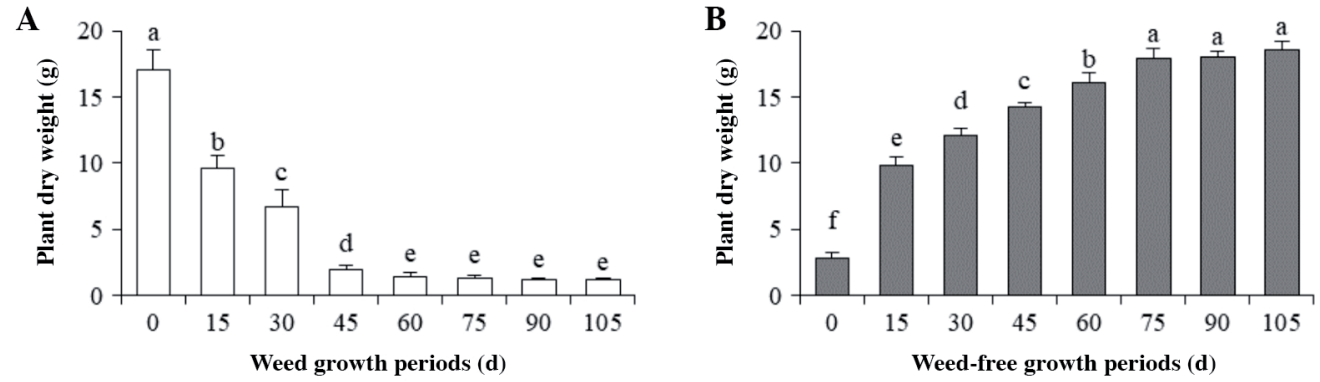

The error bars represent the standard deviation of the mean in each treatment and lower-case letters indicate significant differences between treatments (LSD test $\mathrm{P} \leq 0.05$ ). 
Figure 5. Grain number per plant response to weed interference in the quinoa 'Regalona' crop in the growth periods (A) with weeds and $(B)$ weed-free.
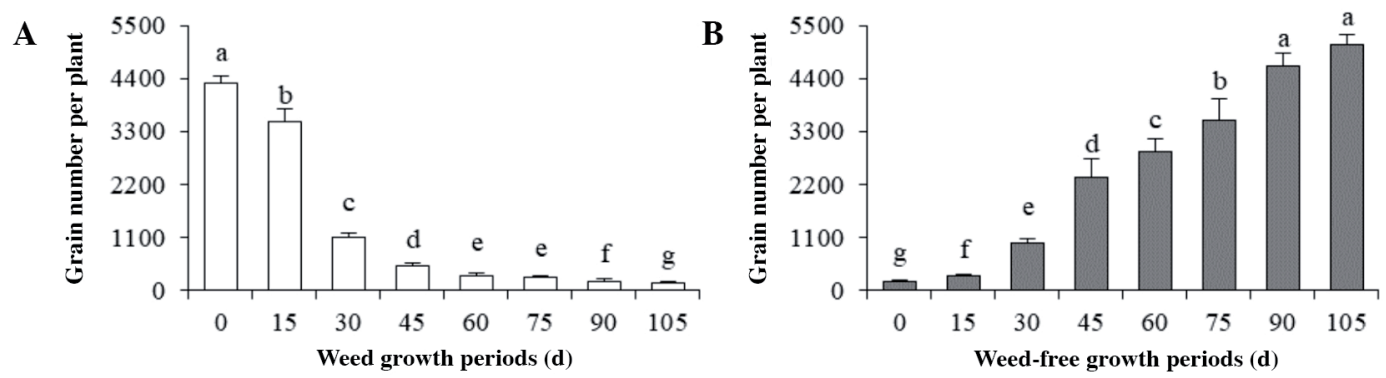

The error bars represent the standard deviation of the mean in each treatment and lower-case letters indicate significant differences between treatments (LSD test $\mathrm{P} \leq 0.05$ ).

Figure 6. Response of 1000 grains weight to weed interference in the quinoa 'Regalona' crop in the growth periods (A) with weeds and $(B)$ weed-free.
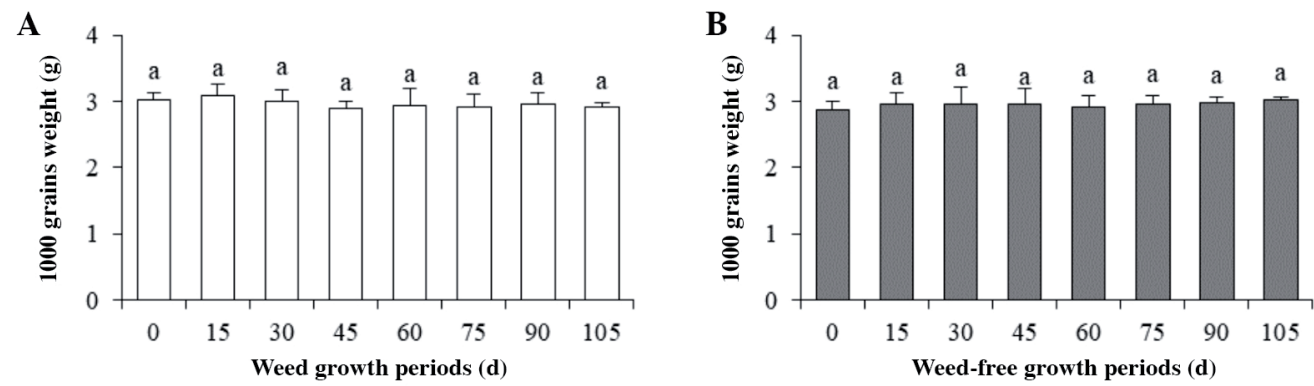

The error bars represent the standard deviation of the mean in each treatment and lower-case letters indicate significant differences between treatments (LSD test $\mathrm{P} \leq 0.05$ )

The PH, plant biomass, and grain number per plant showed their highest values in those treatments that remained weedfree during the experiment, while the lowest values were recorded in the treatments that were weed-infested. This is due to the effect of weeds on the development of crops, competing for water, light, nutrients, $\mathrm{CO}_{2}$ and space, behaving as hosts of pests and diseases (Page et al., 2009), also by the shade effect caused by the highest weeds that reduce available light for photosynthesis and thus biomass production, resulting in decreased yield components (Vasilakoglou and Dhima, 2012).

Akhter et al. (2009) reported a decrease in the yield components of a pea crop under weed conditions. Similar studies in other crops have demonstrated decreased yield components due to weed-crop interference. Safdar et al. (2016) reported decreased yield components in a corn crop and Singh et al. (2016) in a pea crop. Weed interference did not affect grain filling, so that the 1000 grains weight variable was the most stable. It is possible that the quinoa plants that were exposed to a longer period of weed interference responded by only forming the number of grains they were able to fill.

Finally, by the logistic and Gompertz regression equations adjusted for grain relative yield (\%), CPWI was determined for quinoa 'Regalona' at the experimental site between 10 and $75 \mathrm{~d}$ after the emergency corresponding to the phenological stages of 2 true leaves and flowering respectively (Table 5) to not have production losses greater than 5\% (Figure 7). The estimated parameters used in the equations were adjusted to the model $(\mathrm{P}<0.05)$; parameters for the Gompertz equation were the asymptote $a=100.5$, exponential rate $b=9.2$, and the inflection point $X_{0}=0.06$. Meanwhile, parameters for the logistic equation were asymptote $\mathrm{a}=109.8$, yield rate reduction measurement $\mathrm{b}=0.05$, and duration of weed interference $\mathrm{X}_{0}=-0.01$. In similar studies with other crops, Ahymadvand et al. (2009) reported that weight of tubers per plant and total tuber production in a potato crop decreased when the duration of weed interference increased, calculated on the basis of $10 \%$ yield losses by the logistic and Gompertz equations. Tursun et al. (2016) reported that the production of three types of corn was influenced by the duration of weed-free and weed-infested periods and CPWI was determined from the development V1 (1 unfolded leaf) stage and maintained until the V12 (12 unfolded leaves) stage. 
Table 5. Phenological stages of quinoa 'Regalona' crop at each treatment application in two seasons.

\begin{tabular}{cc}
\hline Days after emergence & Phenological stages \\
\hline 0 & Emergence \\
15 & 2 true leaves \\
30 & 6 true leaves \\
45 & Start of panicle formation \\
60 & Start of flowering \\
75 & Flowering \\
90 & Milky grain \\
105 & Physiological maturity \\
\hline
\end{tabular}

Figure 7. Effect of weed control periods on quinoa 'Regalona' yield.

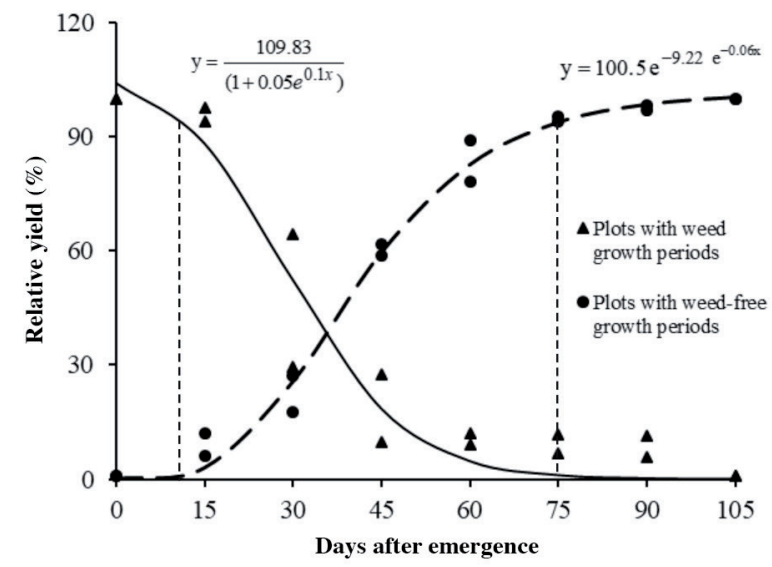

The Gompertz equation was used in weed-free plots and the logistic equation adjusted to grain yield (\% yield) was used in weedinfested plots. The weed-free critical periods to achieve $95 \%$ of the maximum yield are shown between the vertical dashed lines.

\section{Total polyphenols}

Total polyphenols varied and increased as the duration of weed interference increased and decreased when the duration of weed interference decreased $(\mathrm{P}<0.05)$. In the weed growth periods (Figure 8A), polyphenols were increased between 45 and $105 \mathrm{~d}$ with weeds, the treatments at 105 and $90 \mathrm{~d}$ with weeds were significantly equal and exhibited the same high total polyphenol values, 3.6 and $3.4 \mathrm{mg} \mathrm{GAE} \mathrm{g}^{-1}$, respectively, while the lowest values were observed in the totally or partially weeded treatments. The at 0,15 , and $30 \mathrm{~d}$ with weeds were significantly equal and exhibited the lowest total polyphenol values, 2.2, 2.2, and $2.3 \mathrm{mg} \mathrm{GAE} \mathrm{g}^{-1}$, respectively. In the weed-free growth periods (Figure 8B), polyphenols

Figure 8. Total polyphenol response to weed interference in the quinoa 'Regalona' crop in the growth periods (A) with weeds and $(B)$ weed-free.
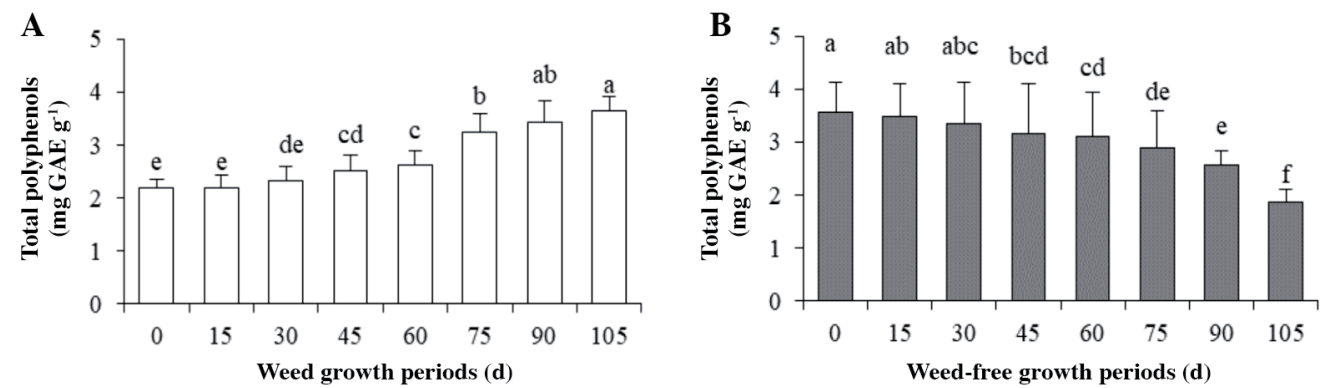

The error bars represent the standard deviation of the mean in each treatment and lower-case letters indicate significant differences between treatments (LSD test $\mathrm{P} \leq 0.05$ ).

GAE: Gallic acid equivalent. 
were decreased between 0 and $90 \mathrm{~d}$ weed-free, the weed-free treatments at 0,15 , and $30 \mathrm{~d}$ were statistically equal and exhibited the highest total polyphenol values, 3.6, 3.5, and 3.4 $\mathrm{mg} \mathrm{GAE} \mathrm{g}^{-1}$, respectively, while the lowest value was 1.9 $\mathrm{mg} \mathrm{GAE} \mathrm{g}^{-1}$ in the totally weeded treatment (105 $\mathrm{d}$ weed-free). Most secondary metabolites found in plants accomplish important functions such as protecting against parasites, conferring attractive characteristics for pollinators and seed dispersers, as well as an important role in plant-plant competition in plant-microorganism symbiosis (Olivoto et al., 2016). In the present study, stress caused by weed interference increased total polyphenol concentration as weedy periods increased. Polyphenols are secondary metabolites that are important in plants and accomplish functions in response to stress conditions (Miranda et al., 2013). Reported mean values in some studies indicate that total phenol content in quinoa grains is $1.1 \mathrm{mg} \mathrm{GAE} \mathrm{g}^{-1}$, and these values are higher than those obtained in traditional cereal seeds such as barley, wheat, rice, and millet that varied between 0.16 and $0.36 \mathrm{GAE} \mathrm{g}^{-1}$ (Asao and Watanabe, 2010; Djordjevic et al., 2010). Meanwhile, Fischer et al. (2013) determined the variation of the antioxidant capacity in quinoa subjected to different water stress levels and found an increase in total polyphenol content between 3.3 and $4.5 \mathrm{mg} \mathrm{GAE} \mathrm{g}^{-1}$ as water restriction increased in the quinoa 'Regalona' crop under field conditions. Miranda et al. (2010) also determined a notable reduction in total polyphenol content when quinoa seed was subjected to high temperatures with hot air.

\section{CONCLUSIONS}

The critical period of weed interference was determined between 10 and $75 \mathrm{~d}$ after the emergency, which corresponded to the phenological stages of two true leaves and flowering, respectively. The determination of this period will allow crop management decision-making to minimize losses produced by weed interference. Stress caused by weed interference altered polyphenol contents and affected quinoa production. Among the yield components, the grain number per plant showed the greatest differences and directly affected yield. Total polyphenols varied and increased with a longer weed interference period, while they decreased with a shorter weed interference period. Thus, in the weed growth periods, polyphenols increased between 45 and $105 \mathrm{~d}$ with weeds, whereas polyphenols decreased between 0 and $90 \mathrm{~d}$ weed-free in the weed-free growth periods. Higher amount total polyphenols in the quinoa crop and lower crop yield were due to stress caused by weed interference.

\section{ACKNOWLEDGEMENTS}

We thank the Secretaría de Educación Superior, Ciencia, Tecnología e Innovación (SENESCYT, Ecuador) and the Instituto Nacional de Investigaciones Agropecuarias (INIAP, Ecuador) for providing a doctoral scholarship to Jorge Luis Merino Toro.

\section{REFERENCES}

Abugoch, J. 2009. Quinoa (Chenopodium quinoa Willd.): composition chemistry, nutritional, and functional properties. Advances in Food and Nutrition Research 58:1-31.

Ahymadvand, G., Mondani, F., and Golzardi, F. 2009. Effect of crop plant density on critical period of weed competition in potato. Scientia Horticulturae 121:249-254.

Akhter, N., Rahman, M., Hasanuzzaman, M., and Nahar, K. 2009. Plant characters and seed yield of garden pea under different light intensity. American-Eurasian Journal of Agronomy 2(3):152-155.

Alvarez-Jubete L., Arendt, E.K., and Gallagher, E. 2010. Nutritive value of pseudocereals and their increasing use as functional gluten free ingredients. Trends in Food Science and Technology 21:106-113.

Asao, M., and Watanabe, K. 2010. Functional and bioactive properties of quinoa and amaranth. Food Science and Technology Research 16(2):163-168.

De Abreu, I., and Mazzafera, P. 2005. Effect of water and temperature stress on the content of active constituents of Hypericum brasilienne Choisy. Plant Physiology and Biochemistry 43:241-248.

Di Rienzo, J.A., Casanoves, F., Balzarini, M.G., Gonzalez, L., Tablada, M., y Robledo, C.W. InfoStat versión 2017. Grupo InfoStat, Facultad de Ciencias Agrarias, Universidad Nacional de Córdoba, Córdoba, Argentina.

Dini, I., Tenore, G.C., and Dini, A. 2010. Antioxidant compound contents and antioxidant activity before and after cooking in sweet and bitter Chenopodium quinoa seeds. LWT-Food Science and Technology 43:447-451. 
Djordjevic, T., Siler-Marinkovic, S., and Dimitrijevic-Brankovic, S. 2010. Antioxidant activity and total phenolic content in some cereals and legumes. International Journal of Food Properties 14(1):175-184.

Fahad, S., Hussain, S., Saud, S., Hassan, S., Muhammad, H., Shan, D., et al. 2014. Consequences of narrow crop row spacing and delayed Echinochloa colona and Trianthema portulacastrum emergence for weed growth and crop yield loss in maize. Weed Research 54:475-483.

Fischer, S., Wilckens, R., Jara, J., and Aranda, M. 2013. Variation in antioxidant capacity of quinoa (Chenopodium quinoa Will) subjected to drought stress. Industrial Crops and Products 46:341-349.

Giménez, E., Delgado, I., and Gómez, F. 2013. Effect of salinity and temperature on seed germination in Limonium cossonianum. Botany 91:12-16.

Karkanis, A., Bilalis, D., Efthimiadou, A., and Katsenios, N. 2012. The critical period for weed competition in parsley (Petroselinum crispum (Mill.) Nyman ex A.W. Hill) in Mediterranean areas. Crop Protection 42:268-272.

Miranda, M., Vega-Gálvez, A., López, L., Parada, G., Sanders, M., Aranda, M., et al. 2010. Impact of air-drying temperature on nutritional properties, total phenolic content and antioxidant capacity of quinoa seeds (Chenopodium quinoa Willd.) Industrial Crops and Products 32:258-263.

Miranda, M., Vega-Gálvez, A., Martínez, E., López, J., Marín, R., Aranda, M., et al. 2013. Influence of contrasting environments on seed composition of two quinoa genotypes: nutritional and functional properties. Chilean Journal of Agricultural Research 73:108-116.

Mujica, A., y Canahua, A. 1989. Fases fenológicas del cultivo de la quinua (Chenopodium quinoa Willd.) p. 23-27. In Curso taller Fenología de Cultivos Andinos y Uso de la Información Agrometeorológica, Salcedo. 7-10 August. Instituto Nacional de Investigacion Agraria y Agroindustrial (INIAA), Estación Experimental de Zonas Áridas (EEZA)-Illpa, Pica, Pisa, Puno, Perú.

Oerke, E. 2006. Crop losses to pests, Journal of Agricultural Science 144:31-43.

Olivoto, T., Nardino, M., Carvalho, I., Follmann, D., Szareski, V., Ferrari, M., et al. 2016. Plant secondary metabolites and its dynamical systems of induction in response to environmental factors: A review. African Journal of Agricultural Research 2(12):71-84.

Page, E., Tollenaar, M., Lee, E., Lukens, L., and Swanton, C. 2009. Does the shade avoidance response contribute to the critical period for weed control in maize (Zea mays L.)? Weed Research 49:563-571.

Pasko,P., Sajewicz, M., Gorinstein, S., and Zachwieja,Z. 2008. Analysis of selected phenolic acids and flavonoids in Amaranthus cruentus and Chenopodium quinoa seeds and sprouts by HPLC. Acta Chromomatographica 20:661-672.

Qasem, J. 2009. Weed competition in cauliflower (Brassica oleracea L. var. botrytis) in the Jordan Valley. Scientia Horticulturae 121:255-259.

Repo-Carrasco-Valencia, R., Hellström, J., Pihlava, J., and Mattila, P. 2010. Flavonoids and other phenolic compounds in Andean indigenous grains: Quinoa (Chenopodium quinoa Willd.), kañiwa (Chenopodium pallidicaule) and kiwicha (Amaranthus caudatus). Food Chemistry 120(1):128-133.

Safdar, M., Tanveer, A., Khaliq, A., and Maqbool, R. 2016. Critical competition period of parthenium weed (Parthenium hysterophorus L.) in maize. Crop Protection 80:101-107.

Singh, M., Bhullar, M., Bhagirath S., and Chauhan, B. 2014. The critical period for weed control in dry-seeded rice. Crop Protection 66:80-85.

Singh, M., Kumar, R., Kumar, S., and Kumar, V. 2016. Critical period for weed control in field pea. Legume Research 39(1):86-90.

Stagnari, F., and Pisante, M. 2011. The critical period for weed competition in French bean (Phaseolus vulgaris L.) in Mediterranean areas. Crop Protection 30:179-184.

Swanton, C., Nkoa, R., and Blackshaw, R. 2015. Experimental methods for crop-weed competition studies. Weed Science 63:2-11.

Tursun, N., Akinci, I., Uludag, A., Pamukoglu, Z., and Gozku, D. 2012. Critical period for weed control in direct seeded red pepper (Capsicum annum L.) Weed Biology and Management 12:109-115.

Tursun, N., Datta, A., Sami Sakinmaz, M., Kantarci, Z., Knezevic, S., and Singh Chauhan, B. 2016. The critical period for weed control in three corn (Zea mays L.) types. Crop Protection 90:59-65.

Vasilakoglou, L., and Dhima, K. 2012. Leafy and semi-leafless field pea competition with winter wild oat as affected by weed density. Field Crop Research 126:130-136. 